НОВОСТАВСКИЙ Игорь Николаевич университет им. И.Т. Трубилина г. Краснодар, Россия novostavskiy@bk.ru

ЖАБЧИК Светлана Викторовна Кубанский государственный аграрный университет им. И.Т. Трубилина

г. Краснодар, Россия

salgir202@rambler.ru

ПоПов Виктор Васильевич

Кубанский государственный аграрный университет им. И.Т. Трубилина

г. Краснодар, Россия

istor-polit@kubsau.ru

УСИЛЕНИЕ МИРОВОЗЗРЕНЧЕСКОЙ
НАПРАВЛЕННОСТИ ПРЕПОДАВАНИЯ
ОБЩЕНАУЧНЫХ И СПЕЦИАЛЬНЫХ
ДИСЦИПЛИН В ВУЗАХ КУБАНИ И ДОНА
В ГОДЫ ІХ И Х ПЯТИЛЕТОК
Кубанский государственный аграрный

Igor N. NOVOSTAVSKIY

Kuban State Agrarian University named after I.T. Trubilin Krasnodar, Russia novostavskiy@bk.ru

Svetlana V. ZHABCHIK Kuban State Agrarian University named after I.T. Trubilin

Krasnodar, Russia salgir202@rambler.ru

Viktor V. POPOV Kuban State Agrarian University named after I.T. Trubilin Krasnodar, Russia istor-polit@kubsau.ru

\section{STRENGTHENING OF WORLD OUTLOOK ORIENTATION OF TEACHING GENERAL SCIENTIFIC AND SPECIAL DISCIPLINES IN HIGHER EDUCATION INSTITUTIONS OF KUBAN AND DON IN DAYS OF IX AND X FIVE-YEARS PERIODS}

В статье рассматривается проблема усиления ми- In article the problem of strengthening of world outровоззренческой направленности преподавания look orientation of teaching general scientific and общенаучных и специальных дисциплин в выс- special disciplines in higher educational institutions ших учебных заведениях Краснодарского края и оf Krasnodar Krai and the Rostov region in days of IX Ростовской области в годы IX и X пятилеток. Объектом исследования стали партийные организации Дона и Кубани, причастные к функционированию и развитию высшей школы. Научная новизна исследования определяется тем, что в историческом аспекте изучены вопросы управления формированием активной жизненной позиции будущих специалистов народного хозяйства страны на основе усиления мировоззренческой направленности преподавания общенаучных и специальных дисциплин. Раскрыта специфика партийного руководства формированием идейнополитических и нравственно-этических установок студенческой молодежи, показана роль кафедр специальных и общественных наук в развитии социальной активности студентов. Собранный и обобщенный авторами материал обогащает общественную практику новыми формами деятельности руководящих органов крупного вузовского региона по стимулированию социальной вовлеченности и активности будущих специалистов народного хозяйства.

Ключевые слова: мировоззрение, специальные и Keywords: outlook, special and social sciences, ideoобщественные науки, идейно-теоретический уро- logical and theoretical level of teaching, higher educaвень преподавания, высшие учебные заведения, tional institutions, student's youth, integrated apстуденческая молодежь, комплексный подход, proach, active living position активная жизненная позиция

Актуальность избранной нами проблемы и недостаточное ее изучение в историческом плане обусловили выбор темы данного исследования. Авторы поставили 
цель - обобщить работу кубанских и донских партийных организаций и администраций высших учебных заведений по повышению мировоззренческой направленности преподавания общенаучных и специальных дисциплин в высших учебных заведениях Краснодарского края и Ростовской области в годы IX и X пятилеток. Хронологические рамки исследования охватывают 1971-1980 гг. Это время расцвета советской высшей школы, обретения ею свойств, надолго определивших ее облик и мировой авторитет.

Объектом исследования стали партийные организации Ростовской области и Краснодарского края, причастные к функционированию и развитию высшей школы. Их выбор объясняется рядом факторов. Во-первых, освещение процесса воспитания студенческой молодежи невозможно без обобщения форм и методов работы партийных структур, поскольку КПСС выполняла функции ведущей и направляющей силы советского общества. Во-вторых, данный регион являлся крупнейшим индустриально-аграрным районом страны, что повышало ответственность партийных организаций за качество подготовки специалистов народного хозяйства, в том числе и в аспекте воспитания. В-третьих, регион представлял собой один из ведущих научных центров, здесь находились крупнейшие вузы Юга России - Ростовский и Кубанский государственные университеты, Новочеркасский и Краснодарский политехнические институты, Кубанский сельскохозяйственный институт и Азово-Черноморский институт механизации сельского хозяйства, Таганрогский радиотехнический институт и ряд других вузов, готовивших для народного хозяйства высококвалифицированные кадры специалистов. В этих вузах проводилась значительная работа по профессиональной подготовке, идейно-политическому, трудовому и нравственному воспитанию молодежи. Источниковую базу исследования составили материалы Центров хранения документации новейшей истории (бывших партийных архивов) Краснодарского края (ЦДНИКК) и Ростовской области (ЦДНИРО). Среди них - стенограммы краевых и областных конференций, пленумов, протоколы заседаний бюро краевого, областного и ряда городских и районных комитетов партии, материалы первичных партийных организаций вузов. Этот массив документов и материалов раскрывает опыт идеологической работы партии, характерные для нее формы, средства и методы воздействия на студенческую молодежь.

Научная новизна исследования определяется тем, что в историческом аспекте изучены вопросы управления формированием активной жизненной позиции будущих специалистов народного хозяйства страны на основе комплексного подхода к воспитанию. Раскрыта специфика партийного руководства формированием идейно-политических и нравственно-этических установок студенческой молодежи, показана роль кафедр общественных наук в развитии социальной активности студентов. Новизна предпринятого нами исследования заключается и в том, что авторами введены в научный оборот ранее не опубликованные архивные документы, которые позволили полнее осветить деятельность партийных организаций по совершенствованию воспитания студенческой молодежи, повышению ее социально-политической активности. Собранный и обобщенный авторами материал обогащает общественную практику новыми формами деятельности руководящих органов крупного вузовского региона по стимулированию социальной вовлеченности и активности будущих специалистов народного хозяйства.

Одним из главных критериев сформированности у личности научного мировоззрения в советский период считалась, на наш взгляд, вполне справедливо, социальная значимость ее деятельности, характер, направленность этой деятельности. В состав научного мировоззрения в советский период было принято включать комплекс компонентов: систему диалектико-материалистических взглядов на развитие природы и общества; комплекс идейно-политических взглядов и представлений, отражавших социальноклассовый подход к событиям и явлениям современного мира и непримиримое, критическое отношение к буржуазной идеологии и всем формам ее проявления; систему научноатеистических взглядов и представлений, опровергающих религию как вид мировоззрения; мировоззренческое содержание нравственных и эстетических идеалов и т.д. Таким образом, процесс формирования научного мировоззрения воспринимался как непосредственно связанный со всеми основными направлениями идейно-политического и нрав- 
ственно-этического воспитания, хотя каждое из них решало и свои специфические задачи [1, c. 375-376].

Формирование научного мировоззрения у студентов происходило во всех сферах их вузовской жизни, как в учебном процессе, так и за его рамками. Свою роль в процессе формирования у студентов научно-материалистического мировоззрения выполняли все дисциплины естественно-научного и гуманитарного цикла. Эта роль становилась тем выше, чем органичнее связывались знания различных учебных дисциплин в едином мировоззренческом контексте, чем последовательней они сводились в единую систему, опиравшуюся на фундамент теории научного социализма.

В 1971 г. в 24 вузах исследуемого региона, готовивших специалистов более чем по 100 специальностям, обучалось 141,7 тыс. студентов. Естественно, что вопросы качества подготовки в вузах специалистов для народного хозяйства страны, их идейной закалки находились в сфере внимания партийных организаций Дона и Кубани. Это нашло свое отражение в материалах XXV Краснодарской, XXVI Новочеркасской, XXIV Таганрогской городских партийных конференций, состоявшихся в январе 1971 г., собрании актива Apмавирской городской парторганизации в апреле того же года [ЦДНИКК. Ф. 1774. Оп. 17. Д. 2, л. 99; ЦДНИКК. Ф. 15. Оп. 23. Д. 9, л. 86, 166; ЦДНИРО. Ф. 105. Оп. 3. Д. 363, л. 144].

Tак, XVI Краснодарская краевая партийная конференция, состоявшаяся 11-12 февраля 1971 г., потребовала от партийных, советских, хозяйственных органов конкретнее заниматься деятельностью вузов, оказывать им практическую помощь в повышении идейной направленности учебно-воспитательного процесса, в формировании у студенческой молодежи научного мировоззрения, трудолюбия, непримиримости к буржуазной идеологии и морали. Конференция подчеркнула, что задачам формирования диалектикоматериалистических взглядов студенчества на природу и общество, их политической зрелости должен быть подчинен весь учебный процесс в вузах [ЦДНИКК. Ф. 1774. Оп. 17. Д. 2, л. 130].

Тема улучшения работы по идейно-нравственному воспитанию студенческой молодежи в ходе учебного процесса обсуждалась и на IV пленуме Ростовского обкома КПСС, состоявшемся в сентябре 1971 г. Наряду с положительными явлениями пленум отметил и слабое влияние некоторых парторганизаций на деятельность коллективов вузов по формированию коммунистических убеждений у будущих специалистов в ходе преподавания специальных и общенаучных дисциплин. Пленум обязал первичные партийные организации высших учебных заведений совершенствовать учебный процесс, идейнотеоретическую направленность всех наук, искать новые формы и методы идеологического воспитания студенчества. Аналогичные задачи были поставлены перед вузовскими парторганизациями на собрании партийного актива Ростовской области, рассмотревшего 20 февраля 1971 г. вопрос «О коммунистическом воспитании учащейся молодежи» [ЦДНИРО. Ф. 9. Оп. 50. Д. 23, л. 12].

Сосредоточив внимание на выполнении решений областного и городских партийных комитетов, вузовские парторганизации Ростовской области усилили внимание к проблемам идейно-нравственного воспитания будущих специалистов в ходе учебного процесса. Так, партком РГУ в марте 1971 г. обсудил вопрос «0 воспитании у студентов марксистско-ленинского материалистического мировоззрения в процессе преподавания общей физики, общей химии и высшей математики». Обсуждению предшествовала серьезная подготовка. Комиссия парткома изучила работу кафедр, ее члены присутствовали на 12 лекциях, ознакомились с учебными планами и документами, беседовали со всеми заведующими кафедрами и отдельными преподавателями. Назовем положительные моменты, которые выявила комиссия: многие профессора и преподаватели в своих лекционных курсах концентрировали внимание студентов на актуальности и научнотеоретической значимости работ В.И. Ленина по вопросам научно-технического прогресса; в учебном процессе широко освещались патриотические традиции и приоритет отечественной науки и техники, обеспечивалась преемственность различных поколений советских ученых. 
Партийный комитет РГУ в то же время отметил и серьезные недостатки: отсутствие на кафедрах единой системы рекомендаций и методических указаний по вопросам методологии и идейного воспитания через предмет, слабую связь общенаучных и специальных дисциплин. В ряде случаев в лекциях по названным дисциплинам вообще не проводилась связь с социальной и этической проблематикой или в научном и методическом отношениях они были слабыми [ЦДНИРО. Ф. 9. Оп. 50. Д. 23, л. 12; ЦДНИРО. Ф. 9. Оп. 50. Д. 88, л. 41].

В исследуемый период Отдел науки и учебных заведений Краснодарского крайкома КПСС уделял должное внимание организации контроля за ходом выполнения постановлений руководящих партийных органов. В Отделе вошло в практику анализировать по протоколам вопросы, обсуждавшиеся на пленумах, собраниях партийного актива и заседаниях бюро горкомов и райкомов партии. Результаты, замечания и предложения доводились до сведения парткомов вузов, что способствовало усилению мировоззренческой направленности преподавания. Так, 10 сентября 1973 г. секретариат крайкома КПСС заслушал вопрос о работе ректората и парткома Кубанского государственного университета по выполнению Постановления ЦК КПСС и СМ СССР по высшей школе от 18 июня 1972 г. В ноябре 1975 г. Отдел науки и учебных заведений проконтролировал ход выполнения принятого Постановления, уделив особое внимание деятельности парткома КГУ по устранению недостатков и упущений в работе с профессорско-преподавательским составом, в обеспечении и усилении мировоззренческой направленности учебновоспитательного процесса.

Партком и ректорат КГУ уделяли постоянное внимание подбору, расстановке и воспитанию кадров. Так, детально было проанализировано положение дел в этом вопросе на математическом, физическом, юридическом и других факультетах. По 23 кафедрам из 47 произошел рост числа преподавателей с учеными степенями и званиями. В течение 1971-1975 гг. численность научно-педагогических кадров повысилась на 87 чел., а доля лиц с учеными степенями и званиями возросла с 40,7\% в 1971 г. до $45 \%$ в 1975 г. [ЦДНИКК. Ф. 1774. Оп. 21. Д. 350, л. 70].

В Кубанском медицинском институте также наметилось улучшение работы по руководству идейной направленностью учебно-воспитательного процесса. Она проводилась в соответствии с разработанным и утвержденным парткомом института перспективным планом идейно-воспитательной работы на весь период обучения, в котором были четко определены обязанности преподавателей всех кафедр по идейнополитическому, нравственному и трудовому воспитанию студенчества. Координацию и контроль за мировоззренческой направленностью учебно-воспитательного процесса стала осуществлять специальная комиссия, возглавляемая членом парткома - проректором по учебно-воспитательной работе. Чаще стала практиковаться и такая форма работы, как отчеты коммунистов о выполнении ими уставных обязанностей, о личном вкладе в политическое воспитание студентов. Так, за три года после выхода Постановления ЦК КПСС и Совета Министров СССР о высшей школе от 1972 г. партком заслушал отчеты 25 коммунистов о повышении ими своего идейно-теоретического уровня, усилении воспитательной ориентированности учебного процесса [ЦДНИКК. Ф. 1774. Оп. 21. Д. 350, л. 28].

Проведенное нами исследование показывает, что в течение 1971-1980 гг. вопросы повышения идейно-теоретического уровня преподавания специальных и общенаучных дисциплин, формирования активной жизненной позиции у будущих специалистов народного хозяйства в учебном процессе находились в сфере внимания городских партийных организаций Краснодарского края и Ростовской области. Они обсуждались на городских партийных конференциях, пленумах, заседаниях бюро и собраниях партийнохозяйственных активов.

Так, Ростовский, Новочеркасский, Краснодарский, Армавирский горкомы КПСС в 1971-1975 гг. на обсуждение бюро выносили такие вопросы: «О состоянии и мерах улучшения учебно-воспитательной работы в Ростовском-на-Дону музыкальнопедагогическом институте», «0 работе Ростовского-на-Дону медицинского института по подготовке высококвалифицированных специалистов в свете решений XXIV съезда 
КПСС», «О состоянии и мерах улучшения подбора, расстановки и воспитания кадров в высших и средних специальных учебных заведениях Октябрьского района г. Ростова-наДону», «0 работе парткома Новочеркасского инженерно-мелиоративного института по повышению авангардной роли коммунистов в выполнении решений XXIV съезда КПСС», «0 политико-воспитательной работе партийной организации Кубанского сельскохозяйственного института», «О работе партийной организации Краснодарского института культуры по выполнению постановления ЦК КПСС и Совета Министров СССР "О мерах по дальнейшему совершенствованию высшего образования в стране"», «О подборе, расстановке и воспитании научных кадров в Армавирском государственном пединституте в свете решений XXIV съезда КПСС», «О работе партийного бюро Армавирского педагогического института по коммунистическому воспитанию студентов» [ЦДНИРО. Ф. 13. Оп. 11. Д. 155, л. 21; ЦДНИРО. Ф. 13. Оп. 11. Д. 158, л. 143; ЦДНИРО. Ф. 13. Оп. 12. Д. 18, л. 92; ЦДНИРО. Ф. 81. Оп. 31. Д. 64, л. 5; ЦДНИРО. Ф. 81. Оп. 31. Д. 68, л. 60; ЦДНИКК. Ф. 1072. Оп. 23. Д. 7, л. 107; ЦДНИКК. Ф. 1072. Оп. 23. Д. 8, л. 8; ЦДНИКК. Ф. 1072. Оп. 24. Д. 9, л. 6; ЦДНИКК. Ф. 15. Оп. 24. Д. 3, л. 108; ЦДНИКК. Ф. 15. Оп. 24. Д. 32, л. 9]. Партийные комитеты серьезное внимание уделяли вопросам улучшения работы вузовских парторганизаций по совершенствованию учебно-воспитательного процесса, его идейно-нравственной направленности, подбору и воспитанию научно-педагогических кадров.

Горкомы партии не только осуществляли контроль за работой вузовских первичных парторганизаций, но и анализировали их деятельность, нацеливали на повышение роли коммунистов в коллективах, их ответственности в деле обучения и воспитания студенчества, вскрывали недостатки в их деятельности, намечали меры по их устранению. Так, бюро Таганрогского горкома КПСС, обсудив 6 марта 1975 г. вопрос «О работе партийного бюро факультета автоматики и вычислительной техники радиотехнического института по руководству учебно-воспитательной работой и научной деятельностью на факультете», отметило, что за 1971-1974 гг. на партийных собраниях факультета ни разу не рассматривались ни методическая работа преподавателей и заведующих кафедрами, ни отчеты коммунистов об их участии в воспитательной работе среди студентов. Бюро горкома КПСС потребовало от парторганизации и деканата факультета усилить внимание к вопросам совершенствования учебно-воспитательного процесса, активнее внедрять новые прогрессивные формы обучения и идейно-нравственного воспитания студенческой молодежи, наметило меры по устранению выявленных недостатков [ЦДНИРО. Ф. 105. Оп. 3. Д. 484, л. 111, 112].

Проведенная работа способствовала усилению внимания парткома ТРТИ к идейной направленности преподавания общенаучных и специальных дисциплин, воспитанию научно-педагогических кадров, повышению их идейно-теоретического уровня. Так, в 1975-1977 гг. на его заседаниях заслушали отчеты всех факультетских парторганизаций по повышению мировоззренческой направленности преподавания общенаучных и специальных дисциплин, провели открытые партийные собрания по проблеме совершенствования коммунистического воспитания студентов в учебном процессе [ЦДНИРО. Ф. 531. Оп. 1. Д. 47, л. 79].

Решения городских партийных органов об усилении воспитательного значения преподавания общенаучных и специальных дисциплин активизировали деятельность парторганизаций и ректоратов вузов. В течение 1971-1976 гг. во многих вузах Ростована-Дону на факультетах проводились собрания с повесткой дня «О задачах партийной организации по улучшению идейно-политического воспитания студентов в учебном процессе». Широко обсуждался, например, этот вопрос на партийном собрании Ростовского государственного университета в июне 1976 г. Участники собрания призвали весь профессорско-преподавательский состав усилить мировоззренческую направленность преподаваемых дисциплин. Деканатам и профилирующим кафедрам предложили всемерно развивать контакты с кафедрами общественных наук, добиваться совместного эффективного воздействия на формирование марксистско-ленинского мировоззрения студентов; на заседаниях кафедр и семинарах преподавателей обсуждать вопросы, каса- 
ющиеся методики и идейно-политического воспитания через предмет [ЦДНИРО. Ф. 689. Оп. 1. Д. 364, л. 74, 75].

В результате проведенной работы в РГУ ввели на старших курсах короткие, по 10-12 часов, факультативные спецкурсы по философским аспектам физики, химии, математики и другим точным и естественным наукам. Парторганизации факультетов и кафедр осуществляли систематический контроль за тем, чтобы в процессе преподавания всех дисциплин решалась задача формирования материалистического мировоззрения у студентов. Задачи партийных организаций по усилению мировоззренческой направленности учебно-воспитательного процесса также рассматривались на партсобраниях в РИСХМ, РИНХ, НПИ и других вузах Ростовской области [ЦДНИРО. Ф. 387. Оп. 1. Д. 65, л. 64, 65, 117, 118; ЦДНИРО. Ф. 691. Оп. 1. Д. 117, л. 72; ЦДНИРО. Ф. 453. Оп. 1. Д. 298, л. 40].

Анализ партийных документов показывает, что исследуемый период характеризовался значительным вниманием к проблемам формирования активной жизненной позиции студентов со стороны районных комитетов КПСС. На заседаниях бюро, собраниях партийно-хозяйственного актива обсуждалась работа первичных парторганизаций вузов по совершенствованию учебно-воспитательного процесса, его идейной направленности. При этом центральное место придавалось поиску новых форм организационнопартийной и идеологической работы, закреплению тех методов, которые хорошо зарекомендовали себя в предыдущие годы.

Так, Октябрьский, Ленинский, Кировский райкомы партии г. Ростова-на-Дону, Первомайский г. Новочеркасска и Ленинский г. Таганрога на заседаниях бюро в течение 1971-1976 гг. заслушивали вопросы: «0 работе парткома РИИЖТа по руководству факультетскими партийными организациями в свете задач, поставленных XXIV съездом КПСС», «О состоянии и мерах по улучшению организаторской работы партийной организации РИИЖТа», «О работе партийного комитета, партийных бюро факультетов РИНХ по руководству партийными группами», «О работе парткома, факультетских партийных организаций РГУ по контролю и организации выполнения принимаемых решений своих и вышестоящих органов», «Отчет о работе парткома НИМИ по руководству партийными группами», «О работе партийного бюро ТГПИ по выполнению постановления ЦК КПСС и Совета Министров СССР "О мерах по дальнейшему совершенствованию высшего образования в стране"» [ЦДНИРО. Ф. 19. Оп. 15. Д. 4, л. 135; ЦДНИРО. Ф. 19. Оп. 19. Д. 10, л. 5; ЦДНИРО. Ф. 17. Оп. 46. Д. 4, л. 140; ЦДНИРО. Ф. 17. Оп. 50. Д. 5, л. 23; ЦДНИРО. Ф. 107. Оп. 1. Д. 1067, л. 37].

Достаточно много внимания уделялось вопросам обеспечения тесного единства обучения и идейно-политического воспитания студенческой молодежи, усиления мировоззренческой направленности преподавания всех дисциплин, изучаемых в вузах.

Проведенная райкомами партии работа способствовала повышению идейнотеоретического уровня учебно-воспитательного процесса, усилению контроля со стороны райкомов КПСС за мировоззренческим и методическим уровнем лекций и семинаров, работе вузовских парторганизаций по повышению научной активности научнопедагогических кадров. Так, в Октябрьском районе г. Ростова-на-Дону в двух зах - РИСХМ и РИИЖТ - в 1975 г. обучалось и работало на 10 факультетах дневного обучения более 10 тыс. чел., партийные организации насчитывали в своих рядах более 1000 коммунистов [ЦДНИРО. Ф. 19. Оп. 18. Д. 1, л. 80]. После того, как Ростовский горком КПСС в декабре 1973 г. изучил состояние и меры улучшения подбора, расстановки и воспитания кадров в высших учебных заведениях Октябрьского района и отметил, что за 1971-1973 гг. бюро райкома ни разу не обсуждало этот вопрос [ЦДНИРО. Ф. 13. Оп. 12. Д. 18, л. 92], здесь значительно улучшилось положение дел. Райком партии усилил внимание к деятельности факультетских парторганизаций, партгрупп кафедр в их работе с кадрами, практиковал заслушивание на заседаниях бюро отчетов заведующих кафедрами о личном участии в идейно-нравственном воспитании студенческой молодежи, организовал учебу преподавателей-коммунистов в семинаре при РК КПСС по актуальным проблемам социально-экономического строительства, внутренней и внешней политики партии [ЦДНИРО. Ф. 689. Оп. 1. Д. 365, л. 52]. 
Под влиянием проведенной работы активизировалась деятельность первичных парторганизаций в РИСХМ и РИИЖТ. В практику работы парткомов вошло составление перспективных планов идейно-воспитательной работы, рассчитанных на весь период обучения, улучшилось руководство учебно-воспитательной и научной работой профессорско-преподавательского состава. Повысилась требовательность к руководителям и педагогическим коллективам за идейно-нравственное воспитание молодежи, качество подготовки специалистов. Так, партком и ректорат РИСХМ, выполняя решения бюро горкома и райкома КПСС, провели глубокий анализ состояния науки и техники, перспектив их развития на ближайшее десятилетие и по его результатам приняли ряд мер. В частности, был четко определен профиль института, по всем девяти специальностям, по которым шла подготовка специалистов, сформулировали требования к инженерам на ближайшее десятилетие, то есть создали модель инженера. На основе выработанных требований профилирующие кафедры разработали мероприятия по усилению мировоззренческой подготовки специалистов. Все кафедры института стали внедрять новые учебные планы, предусматривавшие усиление не только профессиональной, но и идейнонравственной подготовки выпускников. Ректорат и партком разработали эффективную систему вовлечения студентов в научное творчество через учебный процесс путем внедрения научно-исследовательского практикума, провели целенаправленную работу по совершенствованию политического образования профессорско-преподавательского состава и коммунистического воспитания студенческой молодежи [ЦДНИРО. Ф. 19. Оп. 18. Д. 1, л. 77].

В итоге успеваемость студентов повысилась и составила 92,8\% в 1975/76 учебном году против 89,8\% в 1974/75 учебном году. Институт за годы девятой пятилетки подготовил более 5600 высококвалифицированных специалистов, значительно окрепли научно-педагогические кадры. В течение 1971-1975 гг. защитили докторские диссертации 16 чел. (при плане 15), был перевыполнен план по защите кандидатских диссертаций - 127 чел. при плане 106 чел. [ЦДНИРО. Ф. 689. Оп. 1. Д. 365, л. 5, 116]. Все это стало значительным вкладом в развитие сельскохозяйственного машиностроения в Ростовской области, в частности производство зерноуборочных комбайнов. Напомним, что в исследуемый период предприятия области - Ростсельмаш и Таганрогский комбайновый завод, получавшие кадры ИТР, прежде всего от РИСХМ, являлись лидерами отечественного и одними из лидеров мирового комбайностроения [2, с. 37-44].

Заметная активизация работы вузовских парторганизаций по руководству учебновоспитательным процессом, его идейно-теоретической направленностью, повышению личной ответственности коммунистов-преподавателей за формирование марксистсколенинского мировоззрения у студентов произошла к 1975 г. и в Ростовском государственном университете, институте народного хозяйства, Новочеркасском политехническом, Таганрогских радиотехническом и педагогическом институтах [ЦДНИРО. Ф. 691. Оп. 1. Д. 117, л. 46; ЦДНИРО. Ф. 689. Оп. 1. Д. 365, л. 137; ЦДНИРО. Ф. 689. Оп. 1. Д. 382, л. 4; ЦДНИРО. Ф. 453. Оп. 1. Д. 298, л. 38; ЦДНИРО. Ф. 107. Оп. 1. Д. 1106, л. 26].

Исходя из решающей роли преподавателей в формировании идейно-нравственных установок студентов, партийные организации вузов Ростовской области и Краснодарского края в исследуемый период постоянно заботились о политико-идеологической подготовке самих преподавателей общенаучных и специальных дисциплин, о вооружении их теорией научного социализма. Широкое распространение в это время получили различные теоретические и методологические семинары, ежегодные научно-методические конференции, педагогические чтения, система партийного просвещения, университеты марксизма-ленинизма, аттестация профессорско-преподавательского состава.

В целях распространения положительного опыта работы по воспитанию научнопедагогических кадров высшей школы, повышению их идейно-теоретического уровня бюро крайкома КПСС 19 мая 1972 г. обобщило деятельность парткома и ректората Краснодарского политехнического института по проведению общественно-политической аттестации профессорско-преподавательского состава, рекомендовало вузовским парторганизациям перенять опыт КПИ при работе с кадрами. Особое внимание парткомов и 
ректоратов обращалось на необходимость постоянного повышения идейнотеоретического уровня профессоров и преподавателей, глубокое изучение ими социально-политических наук и применение их при преподавании специальных дисциплин, активное участие в политической работе со студентами. Бюро крайкома особо подчеркнуло необходимость взаимодействия ученых, представлявших технические, общественные и естественные науки [ЦДНИКК. Ф. 1774. Оп. 18. Д. 28, л. 8].

Хотя формально постановление бюро крайкома относилось к КПИ, оно стало ориентиром и для парткомов и ректоратов других вузов Кубани. Так, в июле 1972 г. мероприятия по его выполнению разработал партком Кубанского сельскохозяйственного института. В том же году, переняв опыт КПИ, факультетские парторганизации стали проводить ежегодную переаттестацию профессорско-преподавательского состава. В сентябре 1974 г. решением парткома КСХИ была создана специальная, постоянно действующая, комиссия по аттестации идеологических и пропагандистских кадров института, в состав которой вошли члены парткома, представители ректората и общественных организаций [ЦДНИКК. Ф. 13001. Оп. 6. Д. 1, л. 44; ЦДНИКК. Ф. 13001. Оп. 6. Д. 3, л. 11, 74].

Партийные организации других вузов Краснодарского края - Кубанского государственного университета, Кубанского медицинского и Армавирского педагогического институтов - внедрили общественно-политическую аттестацию научно-педагогических кадров значительно позже - в 1976-1977 гг. Так, первая аттестация в КГУ проводилась в 1976 г., а в последующие годы она стала одной из действенных форм контроля парторганизации за уровнем идейно-теоретической подготовки педагогов, их участия в политическом и нравственном воспитании студентов. На факультетах создали аттестационные комиссии для оценки деловых, морально-политических и нравственных качеств сотрудников. Итоги аттестации подвели на заседании ректората КГУ в сентябре и на заседании парткома 10 ноября 1976 г. В ходе аттестации положительную оценку получила деятельность большинства преподавателей, которые осуществляли на высоком уровне учебнометодическую, научно-исследовательскую и воспитательную работу, активно участвовали в общественной жизни, соблюдали трудовую дисциплину.

Партком Ростовского государственного университета практиковал проведение ежегодных общественных аттестаций всех заведующих кафедрами на своих заседаниях, заслушивал отчеты факультетских парторганизаций о повышении научного и педагогического уровня, об общественной аттестации педагогических кадров. В РИИЖТ и РИСХМ переаттестация преподавателей и их конкурсное избрание осуществлялись только после обсуждений каждой кандидатуры на партийных бюро факультетов и на заседаниях парткомов [ЦДНИРО. Ф. 689. Оп. 1. Д. 294, л. 56, 67, 70, 180; ЦДНИРО. Ф. 13. Оп. 14. Д. 60, л. 2].

Аттестация профессорско-преподавательского состава высших учебных заведений, проводимая в исследуемый период вузовскими парторганизациями Дона и Кубани, не подменяла и не дублировала отчеты преподавателей на кафедрах, а углубляла и дополняла их. В ходе аттестации большое внимание уделялось морально-политическому и нравственному облику аттестуемого, его поведению в коллективе, быту, рассматривался круг его интересов, вопросы общественной работы по формированию активной жизненной позиции у студентов. На заседаниях аттестационных комиссий велся принципиальный разговор о недостатках, просчетах в воспитательной работе некоторых коллег, давались рекомендации по их устранению. Во многих вузах региона организовали регулярную учебу руководителей аттестационных комиссий факультетов и обмен опытом. Аттестация превратилась в важное средство повышения требовательности и самодисциплины каждого преподавателя, а в конечном счете - повышения его профессионального уровня и морально-политических качеств.

Парторганизации улучшили политическое информирование профессорскопреподавательского состава. Например, в вузах Ростовской области проводились единые политдни. В 1979/80 учебном году провели политдни по темам: «Постановление ЦК КПСС и Совета Министров СССР "О дальнейшем развитии высшей школы и повышении качества подготовки специалистов" - конкретная программа всестороннего совершенствования высшего образования в стране», «Итоги работы ноябрьского (1979 г.) Пленума ЦК 
КПСС и задачи высшей школы» [ЦДНИРО. Ф. 9. Оп. 70. Д. 118, л. 21]. В организации и проведении единых политдней в вузах приняли участие работники обкома, горкомов и райкомов партии, советские, комсомольские, профсоюзные, хозяйственные руководители, ветераны партии и труда. В Краснодарском политехническом и Кубанском сельскохозяйственном институтах важной формой идейного воспитания педагогов в исследуемый период стали политинформации для профессорско-преподавательского состава. С ними выступали секретари Ленинского райкома КПСС, ректоры вузов, главный архитектор г. Краснодара, председатель краевого Комитета защиты мира, работники Комитета государственной безопасности, руководители предприятий города, директора совхозов и председатели колхозов края [ЦДНИКК. Ф. 2591. Оп. 1. Д. 295, л. 61; ЦДНИКК. Ф. 2591. Оп. 1. Д. 296, л. 31].

Таким образом, изложенный в данном разделе фактический и статистический материал позволяет сделать ряд выводов. Краснодарская краевая и Ростовская областная партийные организации в течение 1971-1980 гг., выполняя решения XXIV и XXV съездов КПСС, последующих Пленумов и Постановлений ЦК КПСС, посвященных вопросам совершенствования идеологической, политико-воспитательной работы и дальнейшего развития высшей школы, провели объемную работу по усилению мировоззренческой направленности преподавания общенаучных и специальных дисциплин.

Может возникнуть вопрос, не отвлекало ли студентов оснащение учебных курсов политико-идеологической и этической проблематикой от изучения собственно общенаучных и специальных дисциплин? Не наносила ли такая гуманитаризация с идеологическим уклоном ущерба профессиональной подготовке молодых специалистов? С нашей точки зрения, на оба эти вопроса можно дать отрицательный ответ. Общеизвестно, что советская высшая школа, особенно техническая, имела очень высокую мировую репутацию. Это доказывает и тот факт, что, когда в ходе глобальных перемен, происходивших в 1990-х годах в России, произошла обвальная деиндустриализация, сотни тысяч ученых, конструкторов, инженеров и иных специалистов с советскими дипломами нашли себе работу по специальности в промышленно развитых странах $[3$, с. 62, 94].

\section{БИБЛИОГРАФИЧЕСКИЕ ССЫЛКИ}

1. XXV съезд Коммунистической партии Советского Союза (4 февраля - 5 марта 1976 г.): Стенограф. отчет. В 3 т. Т. 1. - М.: Политиздат, 1976. - 472 с.

2. Алексеенко О.И. Деятельность органов власти по развитию производства зерноуборочных комбайнов в Ростовской области в 1966-1975 гг. / О.И. Алексеенко // Историческая и социально-образовательная мысль. - Краснодар, 2016. - Т. 8. - № 1. - Ч. 2. - С. 37-44.

3. Улезко Б.В. Социально-политическое регулирование научно-технического прогресса в промышленности Краснодарского края и Ростовской области (1971-1980 гг.): Монография. / Б.В. Улезко. - Краснодар: Изд-во Науч.-исслед. ин-та экономики ЮФО, 2008. - 168 с.

\section{REFERENCES}

1. XXV s"ezd Kommunisticheskoy partii Sovetskogo Soyuza (4 fevralya - 5 marta 1976 g.): [ XXV congress of the Communist Party of the Soviet Union (on February4 - March5, 1976)] stenograf. otchet. V 3 t. T. 1. M.: Politizdat, 1976. 472 p. (in Russ)

2. Alekseenko O.I. Deyatel'nost' organov vlasti po razvitiyu proizvodstva zernouborochnykh kombaynov v Rostovskoy oblasti v 1966-1975 gg. [Activities of authorities for development of production of combine harvesters in the Rostov region in 1966-1975]. O.I. Alekseenko. Istoricheskaya i sotsial'no-obrazovatel'naya mysl'. Krasnodar, 2016. T. 8. № 1. Ch. 2. Pp. 37-44. (in Russ)

3. Ulezko B.V. Sotsial'no-politicheskoe regulirovanie nauchno-tekhnicheskogo progressa v promyshlennosti Krasnodarskogo kraya i Rostovskoy oblasti (1971-1980 gg.). [Socio-political regulation of scientific and technical progress in the industry of Krasnodar Krai and Rostov region (1971-1980)]. monografiya. B.V. Ulezko. Krasnodar: Izd-vo Nauch.-issled. in-ta ekonomiki YuFO, 2008. 168 p. (in Russ) 


\section{Информация об авторах:}

Новоставский Игорь Николаевич, кандидат исторических наук, доцент, Кубанский государственный аграрный университет им. И.Т. Трубилина,

г. Краснодар, Россия

novostavskiy@bk.ru

Жабчик Светлана Викторовна, кандидат исторических наук, доцент, Кубанский государственный аграрный университет им. И.Т. Трубилина,

г. Краснодар, Россия

salgir202@rambler.ru

Попов Виктор Васильевич, кандидат исторических наук, доцент, Кубанский государственный аграрный университет им. И.Т. Трубилина,

г. Краснодар, Россия

istor-polit@kubsau.ru

Получена: 21.02.2018

Для цитирования: Новоставский И.Н., Жабчик С.В., Попов В.В. Усиление мировоззренческой направленности преподавания общенаучных и специальных дисциплин в вузах Кубани и Дона в годы IX и X пятилеток. Историческая и социально-образовательная мысль.

2018. Том. 10. № 2/1 . c.106-115.

DOI: 10.17748/2075-9908-2018-10-2/1-106-115.

\section{Information about the authors:}

Igor N. Novostavskiy, Candidate of Historical Sciences, Associate Professor, Kuban State Agrarian University named after I.T. Trubilin,

Krasnodar, Russia

novostavskiy@bk.ru

Svetlana V. Zhabchik, Candidate of Historical Sciences, Associate Professor, Kuban State Agrarian University named after I.T. Trubilin,

Krasnodar, Russia

salgir202@rambler.ru

Viktor V. Popov, Candidate of Historical Sciences, Associate Professor, Kuban State Agrarian University named after I.T. Trubilin,

Krasnodar, Russia

istor-polit@kubsau.ru

Received:21.02.2018

For citation: Novostavskiy I.N., Zhabchik S.V., Popov V.V. Strengthening of world outlook orientation of teaching general scientific and special disciplines in higher education institutions of Kuban and Don in days of IX and X five-years periods. Historical and Social-Educational Idea. 2018. Vol. 10. no.2/1. Pp. 106-115.

DOI: 10.17748/2075-9908-2018-10-2/1-106-115. (in Russ) 